\title{
Role of Low Environmental Temperature in Peptic Ulcer Development
}

\author{
Funke Ige $\mathrm{S.}^{1 *}$, S. Olateju B. ${ }^{2}$, A. Oladipupo V. ${ }^{3}$, T. Adekola A. ${ }^{4}$, B. Ademilua $0 .^{5}$ \\ DOI: https://doi.org/10.17511/ijmrr.2021.i03.10
}

1* Serah Funke Ige, (PhD), Department of Physiology, Faculty of Basic Medical Sciences, College of Health Sciences, Ladoke Akintola University of Technology, Ogbomoso, , Nigeria.

2 Bolade S. Olateju, (M.Sc), Department of Physiology, College of Medicine University of Lagos, Lagos, Nigeria.

3 Victor A. Oladipupo, (B.Tech), Department of Physiology, Faculty of Basic Medical Sciences, College of Health Sciences, Ladoke Akintola University of Technology, Ogbomoso, Nigeria.

4 Adedayo T. Adekola, (B.Tech), Department of Physiology, Faculty of Basic Medical Sciences, College of Health Sciences, Ladoke Akintola University of Technology, Ogbomoso, Oyo, Nigeria.

5 Oluwaseun B. Ademilua, (B.Tech), Department of Physiology, Faculty of Basic Medical Sciences, College of Health Sciences, Ladoke Akintola University of Technology, Ogbomoso, Oyo, Nigeria.

Peptic ulcers are described as acid-induced lesions found in the stomach and duodenum caused by the imbalance between the defending factors of the mucosa and the attacking factors such as hydrochloric acid in gastric juice, with Helicobacter Pylori (H. Pylori) and Non-Steroidal AntiInflammatory Drugs NSAIDs. They exhibit seasonal patterns in their occurrence, with higher occurrence in winter and spring and a low occurrence in summer. Temperature plays a major role in their occurrence, some of which have resulted in increased morbidity in some number of diseases, such as gastrointestinal bleeding, caused by an increase in air pressure, dry air (relative humidity) occurring from cold air, and also its actions on the protective effect helicobacter pylori in the human body. Their actions excite the adrenal gland marrow and the sympathetic nerve, causing rapid secretion of adrenaline and non-adrenaline, angiotensin II and endothelin, resulting in damage to the mucosa epithelial, caused by the contraction effect of the adrenal agents on the duodenal mucosa and blood vessel. It causes low expression of Epidermal Growth Factor Receptor (EGFR), Epidermal Growth Factor (EGF), Heat Shock Protein (HSP) 70, Occludin, Nitric Oxide Synthase (NOS), in the gastric mucosa, in extremely cold temperature than those in extremely hot temperature, increasing the gastric acid secretion in extremely cold temperature than in extremely hot temperature. Therefore, this review aims to give general insight into the role of low temperature in peptic ulcer development and further consideration in the treatment of peptic ulcer diseases.

Keywords: Peptic Ulcer, Temperature, Helicobacter Pylori (H. Pylori)

Corresponding Author

Serah Funke Ige, (PhD), Department of Physiology, Faculty of Basic Medical Sciences, College of Health Sciences, Ladoke Akintola University of Technology, Ogbomoso, Nigeria.

Email: sfige@lautech.edu.ng
How to Cite this Article

Ige SF, Olateju BS, Oladipupo VA, Adekola AT, Ademilua OB. Role of Low Environmental Temperature in Peptic Ulcer Development. Int J Med Res Rev. 2021;9(3):193-204.

Available From

https://ijmrr.medresearch.in/index.php/ijmrr/article/ view/1293
To Browse

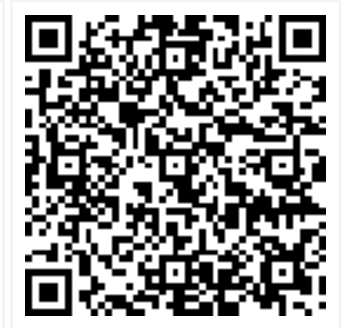

Manuscript Received 2021-05-30

Conflict of Interest No

Review Round 1
2021-06-10
Funding
Nil

Review Round 2
2021-06-20
$\begin{gathered}\text { Ethical Approval } \\ \text { Yes }\end{gathered}$

Review Round 3 2021-06-25

Plagiarism X-checker $7 \%$
Accepted 2021-06-30

Note

(c) 2021 by Serah Funke Ige, Bolade S. Olateju, Victor A. Oladipupo, Adedayo T. Adekola, Oluwaseun B. Ademilua and Published by Siddharth Health Research and Social Welfare Society. This is an Open Access article licensed under a Creative Commons Attribution 4.0 International License https://creativecommons.org/licenses/by/4.0/ unported [CC BY 4.0] 


\section{Introduction}

Peptic ulcers are described as acid-induced lesions found in the stomach and duodenum, characterized by denuded mucosa with its defect extending into the sub-mucosa or muscularis propria, [1]. These diseases tend to share a common pathway of acidpepsin pathogenesis, [2]. The major ones are Duodenal Ulcer (DU) and Gastric Ulcer (GU), [2]. This is due to the imbalance between the defending factors of the mucosa and the attacking factors such as hydrochloric acid in gastric juice [3]. The main risk factors for these diseases are Helicobacter Pylori (H. Pylori) and Non-Steroidal AntiInflammatory Drugs (NSAIDs) $[1,4]$. Ulcerations in the gastro-duodenal tract are seen as defects of the mucosal lining resulting from the epithelial cell damaged brought into play by caustic agents such as acid and pepsin, [5]. These caustic agents prevail over the defensive mechanisms of the gastroduodenal mucosa, observing from a pathophysiological standpoint, [6]. They are not classified as a single entity, rather they are group according to their lesion site, i.e., stomach or duodenum, and presence or absence of complications, i.e., hemorrhage or perforation,[7].

Non-steroidal anti-inflammatory drugs are the most common drugs, used for pain and inflammation reduction, with proven efficacy, [8]. However, they have been said to account for over $90 \%$ of ulcers with substantial implications and complications associated with gastro-intestinal toxicities, $[9,10]$. Its mechanism of action is through COX-1 inhibition in the gastrointestinal tract, leading to a reduction in prostaglandin secretion and gastric mucosa cytoprotective effect, [11]. These all together increases the risk of damage to the mucosa, [11]. Peptic ulcer remains an important cause of morbidity and health care cost, [12]. The natural history of peptic ulcers ranges from healing without intervention to the development of complications such as bleeding and perforation, [12]. In a review study, the pooled incidence of uncomplicated peptic ulcer disease (PUD) was approximately one case per 1000 person-years in the general population and the incidence of ulcer complication was about 0.7 cases per 1000 person, [13]. The cases of PUD vary based upon the presence of Helicobacter pylori. Higher rates are found in countries where Helicobacter pylori infection is higher with approximately 1 percent per year, a case that is 610 fold higher in uninfected individuals, $[14,15,16,17]$.
A population-based one-year prevalence of PUD of 0.1 to 1.5 percent based on physician diagnosis and 0.1 to 0.19 percent based on hospitalization data was recorded by Sung et al., (2009), [18]. In the unitedstates, a study by Anand et al., (1996), [19] reported an endoscopic point prevalence for peptic ulcers in asymptomatic, $\mathrm{H}$. pylori-positive adults of 2 percent. Ulcer incidence increases with age for both duodenal and gastric ulcers, [19].

\section{Role of temperature on helicobacter pylori $(\mathrm{H}$. Pylori)}

Helicobacter pylori, a gram-negative bacterium, infesting more than $50 \%$ of the world population [20], has its home in the human gastric mucosa, causing stomach injury, [21]. Its communication with the receptors of epithelial cells accompanied by endogenous pathways stimulation and its actions on soluble bacterial components alters or destroys the gastric barrier, $[22,20]$. Its ability to survive and endure in an organism has been said to be mediated by the production of catalase by bacteria. $[23,24]$. Vitamin-D and D-receptors in target tissues such as the intestine, immune cells, has also been identified to play an important protective role in $\mathrm{H}$. Pylori infection, $[25,26,27]$. Its synthesis which is in response to sunlight and ultraviolet radiation is affected by season, temperature, latitude, and daily sunshine duration,[28]. A recent study revealed that lower $\mathrm{H}$. pylori infection rates were associated with higher average annual temperature while average daily sunshine time correlated positively with $\mathrm{H}$. pylori infection, [29]. It also revealed that, individuals dwelling at high latitude showed a high H.Pylori infection rates, [29].

Although the mechanism of action of $\mathrm{H}$. Pylori hasn't been understood fully, it has been said to be associated with acute and chronic inflammatory responses with a resultant infection in gastric/duodenal ulcers or the development of gastric cancer, [30]. It was said that, the excessive damage done to the barrier by inflammation allows the movement of $\mathrm{H}$. Pylori-virulence-factors into the circulation resulting in the development of a systematic inflammatory response, [30]. Studies also revealed that, lower decrease in the body immunity functions during the cold season, such as a decrease in the number of outer lymph cells and $B$ lymph cells, makes the duodenal mucosa subjected to attack easily by Helicobacter Pylori resulting in the inhibition of the mucosa growth factors, and the rapid development of a peptic ulcer, $[31,32,33]$. 


\section{Role of Temperature in the Occurrence of Peptic Ulcer}

Large numbers of medical conditions have been observed to exhibit seasonal patterns in their occurrence. Examples are; gastrointestinal diseases and cardiovascular diseases, both occurring with high frequency in winter months, $[34,35,36,37]$. It is characterized by seasons, with a higher occurrence in winter and spring and a low occurrence in summer, [3]. Although $\mathrm{H}$. Pylori and NSAIDs are the major factors responsible for the onset, development, and occurrence of peptic ulcers, only a few studies have been carried out to determine the role of extreme weather and climatic conditions in the development and treatment of peptic ulcer diseases, [1]. Few studies have observed that, temperature plays a major in the occurrence of peptic ulcers, some of which have resulted in increased morbidity in some number of diseases, such as gastrointestinal bleeding, [36, 38, 39], which exhibit a higher frequency in the winter than in the summer, [40].

The actions of temperature on ulcer development have been also said to be caused by an increase in air pressure and dry air relative humidity occurring from cold air, [41,42,43,44]. A series of stress actions have been observed to occur when meteorological factors such as temperature violently change into a severe cold atmosphere i.e., change in temperature, $[40,43]$. These actions excite the adrenal gland marrow and the sympathetic nerve, causing rapid secretion of adrenaline and nonadrenaline, angiotensin II, and endothelin, [31], resulting in damage to the mucosa epithelial, caused by the contraction effect of the adrenal agents on the duodenal mucosa and blood vessel as a result of insufficient oxygen supply, $[42.45 .46,47]$. The stress caused by cold reduces the secretion of inhibitable growth factors, increasing the secretion of hydrochloric acid in gastric juice, accelerating the onset of peptic ulcers, [31].

A recent study examined gastric mucosal damage and its barrier function (through associated barrier factors) under an extremely hot temperature at an average of $>300 \mathrm{c}$ and an extremely cold temperature at an average of $<100 \mathrm{c}$, [48]. Their results revealed low expression of epidermal growth factor receptor (EGFR), epidermal growth factor (EGF), heat shock protein (HSP) 70, occludin, nitric oxide synthase (NOS), in the gastric mucosa, in extreme cold temperature than those in extreme hot temperature, whereas the gastric acid secretion
Was higher in extreme cold temperature than in extreme hot temperature, [48].

\section{Role of Temperature on Mucosa Barrier Proteins}

Mucosal barrier functions are defined by tight junctions, [49]. Tight junctions comprise multiple proteins, including; occludin, heat shock protein, epidermal growth factor, and claudins, which have been characterized as barrier enhancing or poreforming, [48, 49]. They are the most important structural component for the formation of constitutive barrier function in epithelial cells, present on the apical end of the lateral membrane surface in epithelial cells therefore forming a barrier against paracellular transport and maintaining apicobasal cell polarity through their fence function, [50]. Changes to these components that regulate and maintain distinct permeability pathways as well as the mucosal immune stimuli can result in barrier loss, [49].

Nitric Oxide (NO): is a highly reactive molecule playing an important fundamental role in the maintenance of normal vasomotor tone,[51]. It has been said that its degree of expression in the gastric mucosa membrane reflects gastric mucosa blood volume, therefore playing a defensive role in the protection of gastric mucosa, [51]. Its level of expression has been revealed to be low during cold temperatures, [48].

Nitric oxide is a gaseous molecule with autocrine and paracrine effects on many cell types. Nitric oxide is synthesized from the amino acid I-arginine by NO synthase (NOS) and is involved in a myriad of cellular functions including muscle relaxation, neuronal signaling and immune function. It is one of the smallest molecules in nature,[52].

In the gastrointestinal tract, NO participate in the modulation of smooth musculature tone such as regulation of intestinal peristalsis, gastric emptying, antral motor activity, [53]. It also regulates acid and gastric mucus secretion, alkaline production and is involved in the maintenance of mucosa blood flow and also demonstrates gastro-protective properties against different types of aggressive agents. However, a high concentration of NO is related to numerous pathological processes of gastrointestinal tract (GIT. Nitric oxide is produced in the GIT by enzymatic, non-enzymatic or bacteria production mechanisms. For example, xanthine oxidoreductase is an enzyme that under hypoxic conditions can produce NO by reduction of nitrate (NO3-) and 
Nitrite (NO2-).

Nitric oxide can also be formed from dietary nitrate which is in the oral cavity and is reduced by bacterial reductases to nitrite, [54], yielding NO gas after acidification in the gastric lumen, [55]. Nitric oxide production from the reaction of hydrogen peroxide with arginine is an example of the nonenzymatic production of NO, [56]. Nitric oxide is produced by anaerobic bacteria in the colon using nitrite and nitrate as substrate, $[57,58]$.

Some important roles of NO in GIT functions include;

01. Motility: the motility of the GI tract is controlled by enteric inhibitory and excitatory motor neurons that innervate the smooth muscle layer. Distention of the gut by a food bolus is detected by local enteric afferent neurons. About $50 \%$ of the nerves in the enteric nervous system contain NOS which are located in the myenteric and muscle fibres, [59].

02. Secretion and Absorption: Nitric oxide is involved in intestinal water transport by acting directly on the epithelium and blood flow or indirectly by stimulating neuronal reflexes or interactions with other agents. For example, NO activates soluble guanylate cyclase and this result in CGMP generation which is a potent activator of the intestinal secretion, [60].

03. Intestinal inflammation, carcinogenesis and apoptotic processes: nitric oxide is important in maintaining mucosal integrity of the GI tract by several mechanisms. Nitric oxide plays a pivotal role in protecting the GI mucosa from a variety of noxious stimuli through the maintenance of mucosal perfusion,[61,62]. It also plays a critical role in modulating the defensive mechanisms in the GI tract due to its antiinflammatory action and improvement of mucosa integrity. Nitric oxide functions in apoptosis in two ways based on its concentration, low concentration protect B lymphocytes against viral infections whereas high concentrations induce apoptosis, $[63,64]$.

04. Gastrointestinal diseases: impaired NO release is indicated in disease with non-relaxing sphincters or bowel segments like achalasia, [67], and infantile hypertrophic pyloric stenosis, [66].

Heat shock proteins (HSP): They have been said to play a major role in the gastroduodenal defense
Mechanism with their expressions activated by heat shock, an example of which is HSP 70 induced by molecular chaperones, $[67,68]$. It is also said to be involved in various biological activities, such as apoptosis prevention, protection from cytotoxic damage, e.g. from NSAIDs or $\mathrm{H}$. pylori infection, and the facilitation of ulcer healing, $[67,68]$. It has also been revealed to have low expression in the gastric mucosa during cold temperatures, [48].

\section{Epidermal growth factor (EGF) and epidermal growth factor receptor (EGFR) protein: They} have both been revealed to be involved in peptic ulcer healing and re-epithelialization, which has also been found to be associated with gastric mucous surface epithelial cells differentiation, proliferation and migration [69], with their expression significantly low during the cold season, [48].

Epidermal growth factor (EGF) is a 53-amino acid peptide, it plays an important role in regulating and maintaining cell growth or development, survival, migration, apoptosis, proliferation and differentiation by binding to epidermal growth factor receptor (EGFR), [70]. It is an effective intestinal regulator helping to protect intestinal barrier integrity which is important in the absorption of nutrients and health in humans and animals[70]. According to Zeng and Harris (2014),[71], it has been detected in a variety of body fluids such as saliva, milk, amniotic fluid, urine, plasma, and intestinal fluid.

Epidermal Growth Factor also functions as a gastrointestinal tract (GI) mucosal protective factor, which associates with intestinal maturation and maintenance of epithelial cell homeostasis in the small intestine, [72]. Some importance of EGF on stomach and duodenal function include the following;

01. Regulation of Tight Junction: tight junction regulates the passage of ions, water and solute and solutes and acts as a fence to maintain cell polarity by blocking the free diffusion of proteins and lipids between the apical and basolateral domains of the plasma membrane, [73].The epidermal Growth Factor is a key regulator of epithelial permeability, a property that depends on Tight Junctions, $[74,75]$. Epidermal Growth Factor has been shown to protect intestinal barrier function by preventing early-weaned, [76], hydrogen peroxide, $[77,78,79]$, ethanol [80], acetaldehyde, $[81,82,83]$ and intestinal ischemia-reperfusion [84,85], induced disruption of Tight Junctions and permeability. 
$\mathrm{Xu}$ et al.(2015) [76], indicated that the oral administration of EGF could improve the gene expression of tight junction proteins such as ZO1 , claudin-1, and occludin, thus enhancing the intestinal barrier function of early-weaned piglets. Hydrogen peroxide-induced intestinal barrier disruption was prevented by Epidermal Growth Factor through Mitogen-activated Protein Kinase (MAPK) and Protein Kinase C(PKC) pathways.

Epidermal Growth Factor induces changes in the composition of Tight Junctions (TJ) through activating several signalling pathways such as Protein Kinase C (PKC),[78], Mitogen-activated Protein Kinase (MAPK),[74] and Signal Transducers and Activators Transcriptions (STATs) in different types of cells, [86].

PKC pathway: Protein Kinase $C$ is a family of serine/threonine protein kinases that plays an important role in controlling the function of other proteins and in several signal transduction cascades, $[87,88]$. Protein Kinase $C$ enzymes are activated by signals including the increased concentration of diacylglycerol (DAG) or calcium ion, [89]. The PKC family consists of fifteen isoenzymes in humans, [90]. These isoenzymes are divided into three subfamilies of conventional, novel and atypical, [91]. Protein Kinase $C$ is transported to the plasma membrane after activation and it helps in the contraction of smooth muscles in the GIT, $[92,93]$.

MAPK pathway: This pathway is also known as the Ras-Raf-MEK-ERK pathway, it is a chain of proteins in the cell that relates information within the cell through the communication of signals from a receptor on the surface of the cell to the DNA in the nucleus of the cell which leads to some changes in the cell such as cell division, [94].

The MAPK pathway plays a major role in integrating and relating external signals from the presence of mitogens such as epidermal growth factors (EGF) into signalling events thereby promoting cell growth and proliferation in many mammalian cell types, [95].

Activated MAPK can phosphorylate a wide range of substrates and thereby affecting a broad array of cellular functions including motility and proliferation. It was shown in a recent study that the MAPK pathway is involved in the regulation of TJ proteins in mouse epididymis, [96].
The contradictory effect of MAPK activation is more pronounced in $\mathrm{TJ}$ integrity where its activation leads to disruption of TJs in some epithelial monolayers and prevention in other epithelia, this was observed in Caco-2 cell monolayers by Aggarwal et al., (2011), [97].

STATs pathway: it is a chain of interactions or communication between proteins in a cell that is involved in processes such as immunity, cell division, cell death and tumor formation. This pathway communicates and relates information from chemical signals from outside of a cell to the cell nucleus resulting in the activation of genes transcription, [98]. Disruption to this pathway can cause serious diseases such as cancers, immune system disorders and skin conditions, [98].

01. EGF Promotes Mucin Secretion: The EGF protects and separates itself physically from exogenous stress by secreting mucins to form a thick protective layer of mucus over the intestinal mucosa which are important for intestinal lubrication, limiting bacteria adhesion and maintaining proper intestinal permeability, $[99,100,101]$.

02. EGF Reduces Bacterial Colonization: The intestinal microbiota profile plays an essential role in intestinal integrity. EGF can reduce colonization of the intestinal epithelium by entero-pathogens, such as Escherichia coli (E.coli),[102,76,103,104] Campylobacter jejuni (C.jejuni),[105], and Enterococcus.[102].

03. EGF and intestinal development: EGF plays a significant role in intestinal development, including increasing villous height and crypt depth, enhancing enterocyte proliferation, and stimulating secretion of digestive enzymes such as trypsin, chymotrypsin, alkalinephosphatase, sucrase, maltase, and lactase, which is important for improving nutrition absorption, feed utilization, and growth performance of animals, $[76,99,102,106,107,108]$.

04. Other importance includes inhibition of acid secretion, protects gastric mucosa against injury, mediates inflammation, mediates mucosa adaptation and accelerates ulcer healing.

The biological functions of EGF a remediated through binding to EGFR and subsequent activation of various signal transduction pathways to regulate intestinal development, Tight Junctions expression and mucins secretion which is important for the formation of intestinal barrier functions, $[99,106$, 
107]. The epidermal Growth Factor acts as a key epithelial mucosa regulator to regulate intestinal permeability and intestinal barrier integrity.

\section{Conclusion}

In summary, the cold temperature has been identified to be one of the major factors in the occurrence of peptic ulcer, performing its functions by directly acting on the adrenal glands to increase the secretion of endothelin, adrenaline, which exerts their contracting effect on the duodenal mucosa and blood vessel resulting in mucosa damage. It also plays a major role by limiting the expression of mucosa barrier proteins; which are the major defence proteins against helicobacter pylori and non-steroidal anti-inflammatory drugs. Therefore, giving the dearth knowledge of the role of temperature in the treatment of peptic ulcer diseases, it is very important to consider temperature as one of the major factors in the treatment of peptic ulcer diseases.

\section{Reference}

01. Feldman, Mark, Lawrence Samuel Friedman, and Lawrence J Brandt, eds. Sleisenger and Fordtran's gastrointestinal and liver disease E-bookpathophysiology, diagnosis, management. Elsevier. Vol 1;2020. [Crossref][PubMed][Google Scholar]

02. pdisease- pathophysiology/diagnosis/ management. Tenth edition. ed Philadelphia, PASaunders/Elsevier. 2016;2;2369-2389. [Crossref] [PubMed][Google Scholar]

03. McGuigan JE. Peptic ulcer and gastritis, In Harrison's Principles of Internal Medicine 12th edition, Edited by- Wilson JD, Braunwald E, Isselbacher KJ, Petersdorf RG, Martin JB, Fauci AS, Root RK. New York- McGraw-Hill. 1991;1229-1248. [Crossref][PubMed][Google Scholar]

04. Liu DY, Gao AN, Tang GD, Yang WY, Qin J, Wu $X G$, et al. Relationship between onset of peptic ulcer and meteorological factors. World J Gastroenterol. 2006 Mar 7;12(9)1463-7. doi: 10.3748/wjg.v12.i9.1463 [Crossref][PubMed] [Google Scholar]

05. Zhang BB, Li Y, Liu XQ, Wang PJ, Yang B, Bian $D L$. Association between vacA genotypes and the risk of duodenal ulcer- a meta-analysis. Mol Biol Rep. 2014 Nov;41(11)7241-54. doi: 10.1007/s11033-014-3610-y [Crossref][PubMed] [Google Scholar]
06. Yuan Y, Padol IT, Hunt RH. Peptic ulcer disease today. Nat Clin Pract Gastroenterol Hepatol. 2006 Feb;3(2)80-9. doi: 10.1038/ncpgasthep0393 [Crossref][PubMed][Google Scholar]

07. Laine L, Takeuchi K, Tarnawski A. Gastric mucosal defense and cytoprotection- bench to bedside. Gastroenterology. 2008 Jul;135(1)41-60. doi: $\quad 10.1053 / j$.gastro.2008.05.030 [Crossref] [PubMed][Google Scholar]

08. Manfredini R, Manfredini F, Boari B, Bergami E, Mari E, Gamberini S, Salmi R, Gallerani M. Seasonal and weekly patterns of hospital admissions for nonfatal and fatal myocardial infarction. Am J Emerg Med. 2009;27(9)1097-103. doi: 10.1016/j.ajem. 2008.08.009 [Crossref][PubMed][Google Scholar]

09. Lanza FL, Chan FK, Quigley EM. Practice Parameters Committee of the American College of Gastroenterology, Guidelines for prevention of NSAID-related ulcer complications. Am J Gastroenterol. 2009;104(3)728-38. doi: 10.1038/ ajg.2009.115 [Crossref][PubMed][Google Scholar]

10. Atchison JW, Herndon CM, Rusie E. NSAIDs for musculoskeletal pain management- current perspectives and novel strategies to improve safety. J Manag Care Pharm. 2013 Nov-Dec;19(9 Suppl A)S3-19. [Crossref][PubMed][Google Scholar]

11. Smalley WE, Griffin MR, Fought RL, Ray WA. Excess costs from gastrointestinal disease associated with nonsteroidal anti-inflammatory drugs. J Gen Intern Med. 1996 Aug;11(8)461-9. doi: $10.1007 / B F 02599040 \quad$ [Crossref][PubMed] [Google Scholar]

12. Brune K, Patrignani P. New insights into the use of currently available non-steroidal antiinflammatory drugs. J Pain Res. 2015 Feb 20;8;10518. doi: 10.2147/JPR.S75160 [Crossref][PubMed] [Google Scholar]

13. Peery AF, Dellon ES, Lund J, Crockett SD, McGowan CE, Bulsiewicz WJ, et al. Burden of gastrointestinal disease in the United States- 2012 update. Gastroenterology. 2012 Nov;143(5)11791187. e3. doi: 10.1053/j.gastro.2012.08.002 [Crossref][PubMed][Google Scholar]

14. Lin KJ, García Rodríguez LA, Hernández-Díaz S. Systematic review of peptic ulcer disease incidence rates- do studies without validation provide reliable estimates?. Pharmacoepidemiol Drug Saf. 2011 Jul;20(7)718-28. doi: 10.1002/pds.2153 [Crossref] [PubMed][Google Scholar] 
15. Li Z, Zou D, Ma X, Chen J, Shi X, Gong Y, et al, Wernersson B, Johansson S, Liu W, He J. Epidemiology of peptic ulcer disease- endoscopic results of the systematic investigation of gastrointestinal disease in China. Am J Gastroenterol. 2010 Dec;105(12)2570-7. doi: 10.1038/ajg.2010.324 [Crossref][PubMed][Google Scholar]

16. Wang FW, Tu MS, Mar GY, Chuang HY, Yu HC, Cheng LC, Hsu PI. Prevalence and risk factors of asymptomatic peptic ulcer disease in Taiwan. World J Gastroenterol. 2011 Mar 7;17(9)1199-203. doi: 10.3748/wjg.v17.i9.1199 [Crossref][PubMed] [Google Scholar]

17. Aro $P$, Storskrubb $T$, Ronkainen J, BollingSternevald E, Engstrand L, Vieth $M$, et al. Peptic ulcer disease in a general adult population- the Kalixanda study- a random population-based study. Am J Epidemiol. 2006 Jun 1;163(11)1025-34. doi: 10.1093/aje/kwj129 [Crossref][PubMed][Google Scholar]

18. Zagari RM, Law GR, Fuccio L, Pozzato P, Forman D, Bazzoli F. Dyspeptic symptoms and endoscopic findings in the community- the Loiano-Monghidoro study. Am J Gastroenterol. 2010 Mar;105(3)565-71. doi: 10.1038/ajg.2009.706 [Crossref][PubMed] [Google Scholar]

19. Sung JJ, Kuipers EJ, El-Serag HB. Systematic review- the global incidence and prevalence of peptic ulcer disease. Aliment Pharmacol Ther. 2009 May 1;29(9)938-46. doi: 10.1111/j.13652036.2009.03960.x [Crossref][PubMed][Google Scholar]

20. Anand BS, Raed AK, Malaty HM, Genta RM, Klein PD, Evans DJ Jr, et al. Low point prevalence of peptic ulcer in normal individuals with Helicobacter pylori infection. Am J Gastroenterol. 1996 Jun;91(6)1112-5. [Crossref][PubMed][Google Scholar]

21. Hatakeyama M. Structure and function of Helicobacter pylori CagA, the first-identified bacterial protein involved in human cancer. Proc JpnAcad Ser B Phys Biol Sci. 2017;93(4)196-219. doi: 10.2183/pjab.93.013 [Crossref][PubMed] [Google Scholar]

22. Peek RM Jr, Blaser MJ. Pathophysiology of Helicobacter pylori-induced gastritis and peptic ulcer disease. Am J Med. 1997 Feb;102(2)200-7. doi: 10.1016/s0002-9343(96)00273-2 [Crossref] [PubMed][Google Scholar]
23. Amieva MR, Vogelmann R, Covacci A, Tompkins LS, Nelson WJ, Falkow S. Disruption of the epithelial apical-junctional complex by Helicobacter pylori CagA. Science. 2003 May 30;300(5624)1430-4. doi: 10.1126/science.1081919 [Crossref][PubMed] [Google Scholar]

24. Fischer W, Prassl S, Haas R. Virulence mechanisms and persistence strategies of the human gastric pathogen Helicobacter pylori. Curr Top Microbiol Immunol. 2009;337;129-71. doi: 10.1007/978-3-642-01846-6_5 [Crossref][PubMed] [Google Scholar]

25. Allen LA. Phagocytosis and persistence of Helicobacter pylori. Cell Microbiol. 2007 Apr;9(4)817-28. doi: 10.1111/j.1462-5822. 2007.00906.x [Crossref][PubMed][Google Scholar]

26. Guo L, Chen W, Zhu H, Chen Y, Wan X, Yang N, et al. Helicobacter pylori induces increased expression of the vitamin $d$ receptor in immune responses. Helicobacter. 2014 Feb;19(1)37-47. doi: 10.1111/hel.12102 [Crossref][PubMed][Google Scholar]

27. Bouillon $R$, Carmeliet $G$, Verlinden $L$, van Etten E, Verstuyf A, Luderer HF, et al. Vitamin D and human health- lessons from vitamin $D$ receptor null mice. Endocr Rev. 2008 Oct;29(6)726-76. doi: 10.1210/er.2008-0004 [Crossref][PubMed][Google Scholar]

28. Gascon-Barré M, Demers C, Mirshahi A, Néron $S$, Zalzal S, Nanci A. The normal liver harbors the vitamin $D$ nuclear receptor in nonparenchymal and biliary epithelial cells. Hepatology. 2003 May;37(5)1034-42. doi: 10.1053/jhep.2003.50176 [Crossref][PubMed][Google Scholar]

29. Holick MF. Environmental factors that influence the cutaneous production of vitamin D. Am J Clin Nutr. 1995 Mar;61(3 Suppl)638S-645S. doi: 10.1093/ajcn/61.3.638S [Crossref][PubMed][Google Scholar]

30. Lu C, Yu Y, Li L, Yu C, Xu P. Systematic review of the relationship of Helicobacter pylori infection with geographical latitude, average annual temperature and average daily sunshine. BMC Gastroenterol. 2018 Apr 17;18(1)50. doi: 10.1186/s12876-0180779-x [Crossref][PubMed][Google Scholar]

31. Blaser MJ, Atherton JC. Helicobacter pylori persistence- biology and disease. J Clin Invest. 2004 Feb;113(3)321-33. doi: 10.1172/JCI20925 [Crossref][PubMed][Google Scholar] 
32. Gang Yang. Endocrinophysiology and Pathologicphysiology, Di'erban. TiangjinTianjinKexue Jishu Chubanshe. 2000;771;782-793, 905-926. [Crossref][PubMed][Google Scholar]

33. Liang $\mathrm{H} \mathrm{J}$, Gao J H, Liu W W, et al. Longterm effects of concentrated Helicobacter pylori culture supernatant on gastric mucosa of rats. Shijie Huaren Xiaohua Zazhi. 7(1999)861-863. [Crossref] [PubMed][Google Scholar]

34. Huo, Shaoshong. "Chronopharmacology and Chronotherapeutics". Diyiban, Tianjin- Tianjin Kexue Jishu Chubanshe. (1994)89-90. [Crossref][PubMed] [Google Scholar]

35. Manfredini $R$, Imberti $D$, Gallerani $M$, Verso $M$, Pistelli R, Ageno W, Agnelli G. Seasonal variation in the occurrence of venous thromboembolis- data from the MASTER Registry. Clin Appl Thromb Hemost. 2009 May-Jun;15(3)309-15. doi: 10.1177/1076029608319947 [Crossref][PubMed] [Google Scholar]

36. Gallerani M, Boari B, Smolensky MH, Salmi R, Fabbri D, Contato E, Manfredini R. Seasonal variation in occurrence of pulmonary embolismanalysis of the database of the Emilia-Romagna region, Italy. Chronobiol Int. 2007;24(1)143-60. doi: 10.1080/07420520601139755 [Crossref] [PubMed][Google Scholar]

37. Vucelić B, Milicić D, Ostojić R, Kern J, Penzar I, Marić $\mathrm{K}$, et al. Utjecajatmosferskihuvjetanaucestalostkrvarenjaizpe ptickogulkusa [The effect of atmospheric conditions on the occurrence of peptic ulcer hemorrhage]. LijecVjesn. 1993 Mar-Apr;115(3-4)70-3. Croatian [Crossref][PubMed][Google Scholar]

38. Mehta RH, Manfredini R, Hassan F, Sechtem U, Bossone $\mathrm{E}$, Oh $\mathrm{JK}$, et al. International Registry of Acute Aortic Dissection (IRAD) Investigators. Chronobiological patterns of acute aortic dissection. Circulation. 2002 Aug 27;106(9)1110-5. doi: 10.1161/01.cir.0000027568.39540.4b [Crossref] [PubMed][Google Scholar]

39. Masclee GM, Valkhoff VE, Coloma PM, de Ridder M, Romio S, Schuemie MJ, Et al. Risk of upper gastrointestinal bleeding from different drug combinations. Gastroenterology. 2014 Oct;147(4)784-792. e9; quiz e13-4. doi: 10.1053/j.gastro.2014.06.007 [Crossref][PubMed] [Google Scholar]
40. Somasundaram S, Sigthorsson G, Simpson RJ, Watts J, Jacob M, Tavares IA, et al. Uncoupling of intestinal mitochondrial oxidative phosphorylation and inhibition of cyclooxygenase are required for the development of NSAID-enteropathy in the rat. Aliment Pharmacol Ther. 2000 May;14(5)639-50. doi: 10.1046/j.1365-2036.2000.00723.x [Crossref] [PubMed][Google Scholar]

41. Bekku D, Arai M, Imazeki F, Yonemitsu Y, Kanda T, Fujiwara $K$, et al. Long-term follow-up of patients with hepatitis $B$ e antigen negative chronic hepatitis B. J Gastroenterol Hepatol. 2011 Jan;26(1)122-8. doi: 10.1111/j.1440-1746.2010.06322.x [Crossref] [PubMed][Google Scholar]

42. Liu DY, Gao AN, Tang GD, Yang WY, Qin J, Wu $X G$, et al. Relationship between onset of peptic ulcer and meteorological factors. World J Gastroenterol. 2006 Mar 7;12(9)1463-7. doi: 10.3748/wjg.v12.i9.1463 [Crossref][PubMed] [Google Scholar]

43. Nomura T, Ohkusa T, Araki A, Chuganji Y, Momoi $M$, Takashimizu I, Watanabe $M$. Influence of climatic factors in the incidence of upper gastrointestinal bleeding. J Gastroenterol Hepatol. 2001 Jun;16(6)619-23. doi: 10.1046/j.14401746.2001.02486.x [Crossref][PubMed][Google Scholar]

44. Lianbo X. Medical Meteorology-The Influence of Weather and Climate Over Health, Diyiban. Shanghai- Knowledge Publishing House. 1984;2528. [Crossref][PubMed][Google Scholar]

45. Zhang J J, Lian Z C, Xu G S, Zhen G Z. Digestive tract of physiology and pathologicphysiology, Diyiban. Guangzhou- Guangdong Keji Chubanshe. 1483 (1997). [Crossref][PubMed][Google Scholar]

46. Kou G, Z S Li. "Endothelin and Gastric Mucosal lijury". Guowai Yixue Xiaohua Jiben Fence. 20(2000)8-11. [Crossref][PubMed][Google Scholar]

47. Li X, Qian J, Chen Y, Chen Y. [The mechanism of somatostatin-induced acid secretion inhibition in isolated parietal cells]. Zhonghua NeiKe Za Zhi. 2001 Apr;40(4)236-8. Chinese [Crossref][PubMed] [Google Scholar]

48. Lu, Zhanglin. "Neuropeptide of Basis Clinic". Diyiban, Shanghai- Dierjunyidaxue Chubanshe. 2000;204-356. [Crossref][PubMed][Google Scholar] 
49. Xiao G, Yuan F, Geng Y, Qiu X, Liu Z, Lu J, et al. Eicosapentaenoic acid enhances heatstrokeimpaired intestinal epithelial barrier function in rats. Shock. 2015 oct;44(4)348-56. Doi: 10.1097/shk.0000000000000417 [Crossref] [PubMed][Google Scholar]

50. France MM, Turner JR. The mucosal barrier at a glance. J Cell Sci. 2017 Jan 15;130(2)307-314. doi: 10.1242/jcs.193482 [Crossref][PubMed][Google Scholar]

51. Tsukita S, Furuse M. The structure and function of claudins, cell adhesion molecules at tight junctions. Ann N Y Acad Sci. 2000;915;129-35. doi: 10.1111/j.1749-6632.2000.tb05235.x [Crossref] [PubMed][Google Scholar]

52. Chen X, Oshima T, Shan J, Fukui H, Watari J, Miwa $H$. Bile salts disrupt human esophageal squamous epithelial barrier function by modulating tight junction proteins. Am J Physiol Gastrointest Liver Physiol. 2012 Jul 15;303(2)G199-208. doi: 10.1152/ajpgi.00454.2011 [Crossref][PubMed] [Google Scholar]

53. Kochar NI, Umathe SN. Beneficial effects of Larginine against diabetes-induced oxidative stress in gastrointestinal tissues in rats. Pharmacol Rep. 2009;61(4)665-72. doi: 10.1016/s1734-1140 (09)70118-5 [Crossref][PubMed][Google Scholar]

54. Moncada S, Higgs A. The L-arginine-nitric oxide pathway. N Engl J Med. 1993 Dec 30;329(27)200212. doi: 10.1056/NEJM199312303292706 [Crossref] [PubMed][Google Scholar]

55. Duncan $C$, Dougall $H$, Johnston $P$, Green $S$, Brogan $R$, Leifert $C$, et al. Chemical generation of nitric oxide in the mouth from the enterosalivary circulation of dietary nitrate. Nat Med. 1995 Jun;1(6)546-51. doi: 10.1038/nm0695-546 [Crossref][PubMed][Google Scholar]

56. McKnight GM, Smith LM, Drummond RS, Duncan CW, Golden M, Benjamin N. Chemical synthesis of nitric oxide in the stomach from dietary nitrate in humans. Gut. 1997;40(2)211-4. doi: 10.1136/gut. 40.2.211 [Crossref][PubMed][Google Scholar]

57. Nagase S, Takemura K, Ueda A, Hirayama A, Aoyagi $K$, Kondoh $M$, Koyama $A$. A novel nonenzymatic pathway for the generation of nitric oxide by the reaction of hydrogen peroxide and Dor L-arginine. BiochemBiophys Res Commun. 1997 Apr 7;233(1)150-3. doi: 10.1006/bbrc.1997.6428 [Crossref][PubMed][Google Scholar]
58. Brittain T, Blackmore R, Greenwood C, Thomson AJ. Bacterial nitrite-reducing enzymes. Eur J Biochem. 1992 Nov 1;209(3)793-802. doi: 10.1111/j.1432-1033.1992.tb17350.x [Crossref] [PubMed][Google Scholar]

59. Goretski J, Zafiriou OC, Hollocher TC. Steadystate nitric oxide concentrations during denitrification. J Biol Chem. 1990 Jul 15;265(20)11535-8. [Crossref][PubMed][Google Scholar]

60. Bult $H$, Boeckxstaens GE, Pelckmans PA, Jordaens FH, Van Maercke YM, Herman AG. Nitric oxide as an inhibitory non-adrenergic noncholinergic neurotransmitter. Nature. 1990 May 24;345(6273)346-7. doi: 10.1038/345346a0 [Crossref][PubMed][Google Scholar]

61. Brasitus TA, Field M, Kimberg DV. Intestinal mucosal cyclic GMP- regulation and relation to ion transport. Am J Physiol. 1976 Jul;231(1)275-82. doi: 10.1152/ajplegacy.1976.231.1.275 [Crossref] [PubMed][Google Scholar]

62. Elliott SN, Wallace JL. Nitric oxide- a regulator of mucosal defense and injury. J Gastroenterol. 1998 Dec;33(6)792-803. doi: 10.1007/s005350050178 [Crossref][PubMed][Google Scholar]

63. Salzman AL. Nitric oxide in the gut. New Horiz. 1995 Feb;3(1)33-45. [Crossref][PubMed][Google Scholar]

64. Albina JE, Cui S, Mateo RB, Reichner JS. Nitric oxide-mediated apoptosis in murine peritoneal macrophages. J Immunol. 1993 Jun $1 ; 150(11) 5080-5$. [Crossref][PubMed][Google Scholar]

65. Clancy R, Rediske J, Koehne C, Stoyanovsky D, Amin A, Attur M, Iyama K, Abramson SB. Activation of stress-activated protein kinase in osteoarthritic cartilage- evidence for nitric oxide dependence. Osteoarthritis Cartilage. 2001 May;9(4)294-9. doi: 10.1053/joca.2000.0388 [Crossref][PubMed] [Google Scholar]

66. Mearin F, Mourelle $M$, Guarner F, Salas A, Riveros-Moreno $\mathrm{V}$, Moncada $\mathrm{S}$, et al. Patients with achalasia lack nitric oxide synthase in the gastrooesophageal junction. Eur J Clin Invest. 1993 Nov;23(11)724-8. doi: 10.1111/j.13652362.1993.tb01292.x [Crossref][PubMed][Google Scholar] 
67. Vanderwinden JM, Mailleux $P$, Schiffmann SN, Vanderhaeghen JJ, De Laet $\mathrm{MH}$. Nitric oxide synthase activity in infantile hypertrophic pyloric stenosis. N Engl J Med. 1992 Aug 20;327(8)511-5. doi: 10.1056/NEJM199208203270802 [Crossref] [PubMed][Google Scholar]

68. Choi SR, Lee SA, Kim YJ, Ok CY, Lee HJ, Hahm $\mathrm{KB}$. Role of heat shock proteins in gastric inflammation and ulcer healing. J PhysiolPharmacol. 2009 Dec;60 Suppl 7;5-17. [Crossref][PubMed] [Google Scholar]

69. Tarnawski AS, Ahluwalia A, Jones MK. The mechanisms of gastric mucosal injury- focus on microvascular endothelium as a key target. Curr Med Chem. 2012;19(1)4-15. doi: $10.2174 / 092986712803414079$ [Crossref][PubMed] [Google Scholar]

70. Syam AF, Sadikin M, Wanandi SI, Rani AA. Molecular mechanism on healing process of peptic ulcer. Acta Med Indones. 2009 Apr;41(2)95-8. [Crossref][PubMed][Google Scholar]

71. Arrieta MC, Bistritz L, Meddings JB. Alterations in intestinal permeability. Gut. 2006 Oct;55(10)1512-20. doi: 10.1136/gut.2005.085373 [Crossref][PubMed][Google Scholar]

72. Zeng F, Harris RC. Epidermal growth factor, from gene organization to bedside. Semin Cell Dev Biol. 2014 Apr;28;2-11. doi: 10.1016/j.semcdb.2014.01.011 [Crossref][PubMed] [Google Scholar]

73. Duh G, Mouri N, Warburton D, Thomas DW. EGF regulates early embryonic mouse gut development in chemically defined organ culture. Pediatr Res. 2000 Dec;48(6)794-802. doi: 10.1203/00006450200012000-00016 [Crossref][PubMed][Google Scholar]

74. Suzuki T. Regulation of intestinal epithelial permeability by tight junctions. Cell Mol Life Sci. 2013 Feb;70(4)631-59. doi: 10.1007/s00018-0121070-x [Crossref][PubMed][Google Scholar]

75. Basuroy S, Seth A, Elias B, Naren AP, Rao R. MAPK interacts with occludin and mediates EGFinduced prevention of tight junction disruption by hydrogen peroxide. Biochem J. 2006 Jan 1;393(Pt 1)69-77. doi: 10.1042/BJ20050959 [Crossref] [PubMed][Google Scholar]
76. Samak G, Aggarwal S, Rao RK. ERK is involved in EGF-mediated protection of tight junctions, but not adherens junctions, in acetaldehyde-treated Caco-2 cell monolayers. Am J Physiol Gastrointest Liver Physiol. 2011 Jul;301(1)G50-9. doi: 10.1152/ajpgi.00494.2010 [Crossref][PubMed] [Google Scholar]

77. Xu S, Wang D, Zhang P, Lin Y, Fang Z, Che L, Wu D. Oral administration of Lactococcus lactisexpressed recombinant porcine epidermal growth factor stimulates the development and promotes the health of small intestines in early-weaned piglets. J Appl Microbiol. 2015 Jul;119(1)225-35. doi: 10.1111/jam.12833 [Crossref][PubMed][Google Scholar]

78. Banan A, Zhang LJ, Farhadi A, Fields JZ, Shaikh $M$, Keshavarzian A. PKC-beta1 isoform activation is required for EGF-induced NF-kappaB inactivation and IkappaBalpha stabilization and protection of $\mathrm{F}$ actin assembly and barrier function in enterocyte monolayers. Am J Physiol Cell Physiol. 2004 Mar;286(3)C723-38.

10.1152/ajpcell.00329.2003 [Crossref][PubMed] [Google Scholar]

79. Banan A, Fields JZ, Talmage DA, Zhang Y, Keshavarzian A. PKC-beta1 mediates EGF protection of microtubules and barrier of intestinal monolayers against oxidants. Am J Physiol Gastrointest Liver Physiol. 2001 Sep;281(3)G833-47. doi: 10.1152/ajpgi.2001.281.3.G833 [Crossref][PubMed] [Google Scholar]

80. Banan A, Fields JZ, Talmage DA, Zhang L, Keshavarzian A. PKC-zeta is required in EGF protection of microtubules and intestinal barrier integrity against oxidant injury. Am J Physiol Gastrointest Liver Physiol. 2002 May;282(5)G794808. doi: 10.1152/ajpgi.00284.2001 [Crossref] [PubMed][Google Scholar]

81. Chen YL, Peng HC, Hsieh YC, Yang SC. Epidermal growth factor improved alcohol-induced inflammation in rats. Alcohol. 2014 Nov;48(7)7016. doi: 10.1016/j.alcohol.2014.07.008 [Crossref] [PubMed][Google Scholar]

82. Basuroy $S$, Sheth $P$, Mansbach CM, Rao RK. Acetaldehyde disrupts tight junctions and adherens junctions in human colonic mucosa- protection by EGF and L-glutamine. Am J Physiol Gastrointest Liver Physiol. 2005 Aug;289(2)G367-75. doi: 10.1152/ajpgi.00464.2004 [Crossref][PubMed] [Google Scholar] 
83. Sheth $P$, Seth A, Thangavel M, Basuroy S, Rao RK. Epidermal growth factor prevents acetaldehydeinduced paracellular permeability in Caco- 2 cell monolayer. Alcohol Clin Exp Res. 2004;28(5)797804. doi: 10.1097/01.alc.0000125358.92335.90 [Crossref][PubMed][Google Scholar]

84. Suzuki T, Seth A, Rao R. Role of phospholipase Cgamma-induced activation of protein kinase Cepsilon (PKCepsilon) and PKCbetaI in epidermal growth factor-mediated protection of tight junctions from acetaldehyde in Caco-2 cell monolayers. J Biol Chem. 2008 Feb 8;283(6)3574-3583. doi: 10.1074/jbc.M709141200 [Crossref][PubMed] [Google Scholar]

85. Arda-Pirincci $P$, Bolkent $S$. The role of epidermal growth factor in prevention of oxidative injury and apoptosis induced by intestinal ischemia/reperfusion in rats. Acta Histochem. 2014 Jan;116(1)167-75. doi: 10.1016/j.acthis.2013.07.005 [Crossref] [PubMed][Google Scholar]

86. Geng Y, Li J, Wang F, Li Q, Wang X, Sun L, Li W. Epidermal growth factor promotes proliferation and improves restoration after intestinal ischemiareperfusion injury in rats. Inflammation. 2013 Jun;36(3)670-9. doi: 10.1007/s10753-012-9591-x [Crossref][PubMed][Google Scholar]

87. García-Hernández V, Flores-Maldonado C, Rincon-Heredia R, Verdejo-Torres O, Bonilla-Delgado J, Meneses-Morales I, et al. EGF regulates claudin-2 and -4 expression through Src and STAT3 in MDCK cells. J Cell Physiol. 2015 Jan;230(1)105-15. doi: 10.1002/jcp.24687 [Crossref][PubMed][Google Scholar]

88. Blumberg PM. Complexities of the protein kinase C pathway. Mol Carcinog. 1991;4(5)339-44. doi: 10.1002/mc.2940040502 [Crossref][PubMed] [Google Scholar]

89. Ali SA, Justilien V, Jamieson L, Murray NR, Fields AP. Protein Kinase $\mathrm{CI}$ Drives a NOTCH3-dependent Stem-like Phenotype in Mutant KRAS Lung Adenocarcinoma. Cancer Cell. 2016 Mar 14;29(3)367-378. doi: 10.1016/j.ccell.2016.02.012 [Crossref][PubMed][Google Scholar]

90. Wilson $\mathrm{CH}$, Ali ES, Scrimgeour N, Martin AM, Hua J, Tallis GA, et al. Steatosis inhibits liver cell store-operated $\mathrm{Ca}^{2+}$ entry and reduces $\mathrm{ER} \mathrm{Ca}{ }^{2+}$ through a protein kinase C-dependent mechanism. Biochem J. 2015 Mar 1;466(2)379-90. doi: 10.1042/B]20140881 [Crossref][PubMed][Google Scholar]
91. Mellor $\mathrm{H}$, Parker PJ. The extended protein kinase C superfamily. Biochem J. 1998 Jun 1;332( Pt 2)(Pt 2)281-92. doi: 10.1042/bj3320281 [Crossref] [PubMed][Google Scholar]

92. Nishizuka Y. Protein kinase $C$ and lipid signaling for sustained cellular responses. FASEB J. 1995;9(7) 484-96. [Crossref][PubMed][Google Scholar]

93. Biancani, Piero, Karen M Harnett. "Signal transduction in lower esophageal sphincter circular muscle". GI Motility online. 2006. [Crossref] [PubMed][Google Scholar]

94. Fitzpatrick D, Purves D, Augustine G. Table 202, Neuroscience (Third ed). Sunderland, MassSinauer. 2004. [Crossref][PubMed][Google Scholar]

95. Orton RJ, Sturm OE, Vyshemirsky V, Calder M, Gilbert DR, Kolch W. Computational modelling of the receptor-tyrosine-kinase-activated MAPK pathway. Biochem J. 2005 Dec 1;392(Pt 2)249-61. doi: 10.1042/B]20050908 [Crossref][PubMed][Google Scholar]

96. Meloche S, Pouysségur J. The ERK1/2 mitogenactivated protein kinase pathway as a master regulator of the $\mathrm{G} 1$ - to S-phase transition. Oncogene. 2007;26(22)3227-39. doi: 10.1038/sj. onc. 1210414 [Crossref][PubMed][Google Scholar]

97. Kim B, Breton S. The MAPK/ERK-Signaling Pathway Regulates the Expression and Distribution of Tight Junction Proteins in the Mouse Proximal Epididymis. Biol Reprod. 2016 Jan;94(1)22. doi: 10.1095/biolreprod.115.134965 [Crossref][PubMed] [Google Scholar]

98. Aggarwal S, Suzuki T, Taylor WL, Bhargava A, Rao RK. Contrasting effects of ERK on tight junction integrity in differentiated and under-differentiated Caco-2 cell monolayers. Biochem J. 2011 Jan 1;433(1)51-63. doi: 10.1042/BJ20100249 [Crossref][PubMed][Google Scholar]

99. Aaronson DS, Horvath CM. A road map for those who don't know JAK-STAT. Science. 2002;296(5573)1653-5. doi: 10.1126/science.107 1545 [Crossref][PubMed][Google Scholar]

100. Bedford A, Chen T, Huynh E, Zhu C, Medeiros $S$, Wey $D$, et al. Epidermal growth factor containing culture supernatant enhances intestine development of early-weaned pigs in vivo- potential mechanisms involved. J Biotechnol. 2015 Feb 20;196-197;9-19. doi: 10.1016/j.jbiotec.2015.01.007 [Crossref] [PubMed][Google Scholar] 
101. Halpern MD, Denning PW. The role of intestinal epithelial barrier function in the development of NEC. Tissue Barriers. 2015 Jan 22;3(1-2)e1000707. doi: 10.1080/21688370.2014.1000707 [Crossref] [PubMed][Google Scholar]

102. Damiano S, Morano A, Ucci V, Accetta R, Mondola $P$, Paternò $R$, et al. Dual oxidase 2 generated reactive oxygen species selectively mediate the induction of mucins by epidermal growth factor in enterocytes. Int J Biochem Cell Biol. 2015 Mar;60;8-18. doi: 10.1016/j.biocel.2014.12.014 [Crossref][PubMed] [Google Scholar]

103. Wang D, Xu S, Lin Y, Fang Z, Che L, Xue B, et al. Recombinant porcine epidermal growth factorsecreting Lactococcus lactis promotes the growth performance of early-weaned piglets. BMC Vet Res. 2014 Aug 21;10;171. doi: 10.1186/s12917-0140171-1 [Crossref][PubMed][Google Scholar]

104. Okuyama $H$, Urao $M$, Lee $D$, Drongowski RA, Coran AG. The effect of epidermal growth factor on bacterial translocation in newborn rabbits. J Pediatr Surg. 1998 Feb;33(2)225-8. doi: 10.1016/s00223468(98)90436-5 [Crossref][PubMed][Google Scholar]

105. Elliott SN, Wallace JL, McKnight W, Gall DG, Hardin JA, Olson M, et al. Bacterial colonization and healing of gastric ulcers- the effects of epidermal growth factor. Am J Physiol Gastrointest Liver Physiol. 2000 Jan;278(1)G105-12. doi: 10.1152/ajpgi.2000.278.1.G105 [Crossref][PubMed] [Google Scholar]
106. Lamb-Rosteski JM, Kalischuk LD, Inglis GD, Buret AG. Epidermal growth factor inhibits Campylobacter jejuni-induced claudin-4 disruption, loss of epithelial barrier function, and Escherichia coli translocation. Infect Immun. 2008 Aug;76(8)3390-8. doi: 10.1128/IAI.01698-07 [Crossref][PubMed][Google Scholar]

107. Lee D N, Chang W F, Yu I T, Chiou P W, Weng C F. Effects of diets supplemented with recombinant epidermal growth factor and glutamine on gastrointestinal tract development of early-weaned piglets. Asian-Australasian Journal of Animal Sciences. 2008;21(4)582-589. [Crossref][PubMed] [Google Scholar]

108. Kang P, Toms D, Yin Y, Cheung Q, Gong J, De Lange $\mathrm{K}, \mathrm{Li}$ J. Epidermal growth factor-expressing Lactococcus lactis enhances intestinal development of early-weaned pigs. J Nutr. 2010 Apr;140(4)80611. doi: 10.3945/jn.109.114173 [Crossref] [PubMed][Google Scholar]

109. Lee DN, Kuo TY, Chen MC, Tang TY, Liu FH, Weng CF. Expression of porcine epidermal growth factor in Pichia pastoris and its biology activity in early-weaned piglets. Life Sci. 2006 Jan 2;78(6)649-54. doi: 10.1016/j.Ifs.2005.05.067 [Crossref][PubMed][Google Scholar] 